\title{
Dynamics of Bcl-2Protein Phosphorylation: A Mini Review
}

\author{
Abdul Manan ${ }^{1 *}$, Sidra Ilyas ${ }^{2}$ \\ 1- Institute of Molecular Biology and Biotechnology (IMBB), The University of Lahore, Lahore, \\ Pakistan \\ 2- University of the Punjab, Dept. of Microbiology and Molecular Genetics (MMG), Lahore, \\ Pakistan.
}

*Corresponding Author: manan319@gmail.com 


\begin{abstract}
The regulation of apoptosis depends upon the Bcl-2 protein family. The process of cell death and survival is highly complicated and regulated by various types of extrinsic as well as intrinsic network of biological system. Several enzymes and regulators play crucial role in cell death and survival cycle not only in healthy but also in pathological state particularly in cancer. In cancerous cells, various proto-oncogenes and anti-apoptotic proteins are activated and responsible for the cell survival and longevity. The mechanism of activation and inactivation of various proteins in cell survival is regulated by the process of phosphorylation (kinases) and dephosphorylation (phosphatases). The current review will summarize the dynamics of Bcl-2 phosphorylation and its role in apoptosis and cell survival.
\end{abstract}

Keywords: apoptosis, cancer, phosphorylation, kinases, Bcl-2

\title{
Introduction
}

Apoptosis or cellular suicide is a genetically programmed process that is important for recycling of damaged cells, tissue homeostasis and embryonic development. The activation mechanism of apoptosis requires extrinsic and intrinsic pathways where various enzymes including cysteine proteases called as "caspases" play a crucial role (Poreba et al., 2019). The activation of caspases at molecular level depends upon the phosphorylation (Parrish et al., 2013). In extrinsic pathway, activated death receptors like tumor necrosis factor receptor (TNFR), TNFrelated apoptosis-induced ligand (TRAIL) and first apoptosis signal (Fas) recruits the initiator caspases (caspase8 and caspase10) (Wang and El-Deiry, 2003; Tummers and Green, 2017). Contrarily, in intrinsic pathway, stress releases cytochrome $\mathrm{c}$ from mitochondria leading to the formation of a complex called "apoptosome" that in turn activate caspase 9 (initiator caspase)which recruit caspase 3 (executioner caspase) in the same way asin extrinsic pathway (Parrish et al., 2013).

Apoptosis is regulated positively by pro-apoptotic protein Bax and negatively by antiapoptotic Bcl-2 family proteins both containing Bcl-2homology (BH) domain (Chipuk and Green, 2008; Brunelle and Letai, 2009). Bcl-2 not only reverses the effect of Bax but also halts the release of cytochrome c from mitochondria (Greenhalf et al., 1996; Gross et al., 2000). Activation/inactivation of pro/anti-apoptotic proteins depends upon the process of 
phosphorylation in which phosphate group from ATP is transferred to one of the amino acid residues of serine, tyrosine or threonine residues by protein kinases (PKs). Imbalance between anti- and pro-apoptotic proteins may lead to inability to respond appropriately to apoptotic stimuli and growth of malignant cells and ultimately cancer that is why cancerous cells do not respond well to treatment (Petros et al., 2004).

In biological system, the regulation of various cellular processes such as signal transduction pathways, apoptosis, cell cycle and growth depend upon proteins. After translation, protein undergoes various changes collectively called post-translational modifications (PTMs) (Hill et al., 2019). These modifications include glycosylation, nitrosylation, methylation, ubiquitination, acetylation, proteolysis, lipidation as well as most important phosphorylation (main topic of the current review). These modifications are not only associated with normal cell's physiology but also the pathological state. Understanding the role of PTMs is very critical for the investigation of disease prevention and treatment (Wang et al., 2014; Zhao and Jensen, 2009).

\section{Phosphorylation}

Phosphorylation and dephosphorylation are two important biological processes catalyzed by protein kinases (PKs) and phosphatases that add or remove a phosphate group of proteins respectively. Study of these momentous processes helps in understanding of not only human health but also the pathological aspects of various disorders including cancer (Seternes et al., 2019). Unique and complete balancing of phosphorylated proteins within a biological system defines its phosphoproteome which is more dynamic than its proteome (Franck et al., 2015).

Phosphorylation acts as a molecular switch to turn the protein in on/off state (Ardito, Fatima, et al. 2017; Colin et al., 2008). Under the influence of phosphorylation three crucial aspects such as interactions, degradation and location control of proteins have been investigated. About one third of proteins undergo phosphorylation and majority is phosphorylated at multiple sites in a single protein. Most common residues are serine and threonine amino acids whereas other amino acids such as tyrosine, glutamic acid, aspartic acid and histidine are also subjected to phosphorylation (Puttick et al., 2008; Hunter, 2009). Higher magnitude of tyrosine phosphorylation has been observed in activated platelets (Ferrell and Martin, 1988). However, most of the cells exhibit highest level of phosphorylation on serine residue and threonine amino acid. 


\section{Bcl-2 family proteins}

The Bcl-2 family protein members and contain one to four functional homology domains (BH1 to BH4) (Petros et al., 2004). Interestingly, Mcl-1 and Bcl-xL show anti-apoptotic role similar to Bcl-2 protein, whereas Bad, Bid and Bax show pro-apoptotic activity. Several members of anti-apoptotic proteins contain all four $\mathrm{BH}$ regions including Ced-9, Bcl-xL, Bcl-w and Bcl-2. Moreover, BHRF1 protein, KSHV-Bcl-2 and Mcl-1 exhibit strong homology sequence in three $\mathrm{BH}$ regions including $\mathrm{BH} 1, \mathrm{BH} 2$ and $\mathrm{BH} 3$ domains. $\mathrm{BH} 3$ region of proapoptotic proteins exhibit interaction with anti-apoptotic members and are responsible for promoting programmed cell death (Letaiet al., 2002; Kvansakul and Hinds, 2013).

The 3D structure of Bcl-2 family members exhibit two central $\alpha$-helices (hydrophobic in nature) that are surrounded by six or seven amphipathic $\alpha$-helices having varying lengths. Interestingly, a prominent hydrophobic groove can be observed on the surface of anti-apoptotic proteins and the residues of this groove are the binding sites for various pro-apoptotic proteins like Bad and Bax containing peptides that mimic BH3 region. Several Bcl-2 family proteins contain a carboxy-terminal hydrophobic region that is accepted for mitochondrial membrane localization. Moreover, membrane localization behavior of anti- and pro-apoptotic proteins is not similar. Bcl-2 and Bcl-xL are localized at cytoplasmic surface of mitochondrial outer membrane; anchoring of these proteins may play a critical role associated with the integrity of mitochondria. Pro-apoptotic members that are present in cytoplasm only localize to outer membrane of mitochondria when they get activated (Petros et al., 2004).

Bcl-2 protein undergoes several types of phosphorylation. One important type occurs during mitosis in un-stressed cells, involving a small proportion of Bcl-2 (Choi and Zhu, 2019). Moreover, investigations by researchers revealed that Thr56, CDK1/cyclin B and JNK were found to be associated with phosphorylation of Bcl-2 protein in mitosis (Yamamoto et al., 1999; Furukawa et al., 2000; Du et al., 2004). Cells treated with anti-mitotic drugs undergo stress which lead to high levels of phosphorylation as observed in all Bcl-2 members and several kinases are involved (Table 1). 
Table 1: Various kinases involve in Bcl-2 phosphorylation

\begin{tabular}{|l|l|l|}
\hline & Name of kinases & References \\
\hline 1 & Raf-1 & Balgosklonny et al., 1997 \\
\hline 2 & PKA & Srivastava et al., 1998 \\
\hline 3 & PKC & Ito et al., 1997; Ruvolo et al., 1998 \\
\hline 4 & MAPK & Breitschopf et al., 2000 \\
\hline 5 & JNK/SAPK & Maundrell et al., 1997 \\
\hline 6 & CDK1 & Terrano et al., 2010 \\
\hline 7 & CDK6 & Ojala et al., 2000 \\
\hline 8 & ASK/JNK & Srivastava et al., 1999 \\
\hline
\end{tabular}

\section{Phosphorylation of Bcl-2 protein}

Under the influence of apoptotic stimuli, Bcl-2 protein performs survival function through inhibition of cytochrome c release from mitochondria. Multiple sites within the Bcl-2 protein have been phosphorylated including Serine at position (70 and 87) and Threonine (56 and 75). Phosphorylation of these sites may be a marker for mitotic cell division as well as targets for ASK/MKK7/JNK1 pathway in anti-cancer therapies (Park et al., 2019).

Bcl-2 phosphorylation in response to a range of treatments is specific to stimuli as well as cell type which lead to the activation or inactivation of anti-apoptotic behavior (Table 2; Figure 1). Role of Bcl-2also depends upon mitochondria, movement of ions and small molecules necessary for induction of cell death. Bcl-2 is present in mitochondria, endoplasmic reticulum and nuclear envelope (Krajewski et al., 1993; Popgeorgiev et al., 2018). Association of Bcl-2 with nuclear matrix is reflecting its important feature in genomic organization (Wang et al., 1999). 
Table 2: Bcl-2 phosphorylation, apoptosis and cell survival

\begin{tabular}{|c|c|c|c|}
\hline Stimulus & Response & Mechanism & Reference \\
\hline Paclitaxel (2hrs) & Apoptosis & $\begin{array}{l}\text { Phosphorylation of Bcl2 (Thr69, Ser70, Ser87) } \\
\text { and was not exclusive for Ser70 }\end{array}$ & $\begin{array}{l}\text { Yamamoto et al., } \\
1999 \\
\text { Haldaret al., } 1995\end{array}$ \\
\hline Paclitaxel & Apoptosis & Bcl-2 phosphorylation without PKC/MAPKs & $\begin{array}{l}\text { Blagosklonny et al., } \\
\text { 1997; Blagosklonny } \\
\text { et al., } 1999\end{array}$ \\
\hline $\begin{array}{l}\text { Glucocorticoid } \\
\text { induction in } \mathrm{T} \text { - } \\
\text { lymphocytes }\end{array}$ & Apoptosis & $\begin{array}{l}\text { (Thr56, Thr74, Ser70, Ser87) } \rightarrow \text { Thr56 and } \\
\text { Ser87 are required for Bcl-2 to protect cells } \\
\text { from glucocorticoid-induced apoptosis }\end{array}$ & Huang et al., 2002 \\
\hline $\begin{array}{l}\text { Nutrient } \\
\text { starvation }\end{array}$ & Apoptosis & $\begin{array}{l}\text { JNK1 activation cause multisite phosphorylation } \\
\text { (Thr69, Ser70, Ser87) of Bcl-2 and dissociation } \\
\text { of Bcl-2-Beclin1 complex }\end{array}$ & Wei et al., 2008 \\
\hline $\begin{array}{l}\text { Multisite } \\
\text { phosphomimetic } \\
\text { mutants }\end{array}$ & Apoptosis & $\begin{array}{l}\text { Phosphorylation } \rightarrow\left(\text { Thr69E }^{*}, \text { Ser70E, Ser87E) }\right. \\
\rightarrow \text { fails to co-immuno precipitate with Beclin1 } \\
\rightarrow \text { fails to inhibit autophagy } \rightarrow \text { all done due to } \\
\text { activated JNK1 } \\
* E \text { is gultamic acid }\end{array}$ & Wei et al., 2008 \\
\hline $\begin{array}{l}\mathrm{Ca}^{2+} \text { conc. in } \\
\mathrm{ER}\end{array}$ & Apoptosis & $\begin{array}{l}\text { Bcl-2 phosphorylation } \rightarrow \text { no binding to both } \\
\text { BH3-only and multi-domain pro-apoptotic } \\
\text { proteins } \rightarrow \text { dissociation of complexes }\end{array}$ & Bassik et al., 2004 \\
\hline $\begin{array}{l}\text { Cellular } \\
\text { starvation }\end{array}$ & Apoptosis & autophagy promoted as cell survival mechanism & $\begin{array}{l}\text { Levine and } \\
\text { Klionsky, } 2004\end{array}$ \\
\hline $\begin{array}{l}\text { Tumor necrosis } \\
\text { factor }(\mathrm{TNF})\end{array}$ & Apoptosis & Prolonged JNK1 activation & Ventura et al., 2006 \\
\hline IL3-withdrawal & Apoptosis & Bcl-2 phosphorylation is inhibited & Ito et al., 1997 \\
\hline p38 MAPK & Apoptosis & $\begin{array}{l}\text { NGF-deprivation, TNF, NO } \rightarrow \text { multisite Bcl-2 } \\
\text { phosphorylation } \rightarrow \text { pro-apoptotic events } \rightarrow\end{array}$ & $\begin{array}{l}\text { Torcia et al., 2001; } \\
\text { Rosini et al., 2000; }\end{array}$ \\
\hline
\end{tabular}




\begin{tabular}{|l|l|l|l|}
\hline & & $\begin{array}{l}\text { release of cytochrome c } \rightarrow \text { in both cellular } \\
\text { system and cell free experiments }\end{array}$ & $\begin{array}{l}\text { Rosini } \text { et al., 2004; } \\
\text { Ishikawa } \text { et al., } \\
\text { 2003; Tamura } \text { et al., } \\
2000\end{array}$ \\
\hline p38 MAPK & $\begin{array}{l}\text { Cell } \\
\text { survival }\end{array}$ & $\begin{array}{l}\text { Bcl-2 phosphorylation } \rightarrow \text { specific targets } \\
\text { (Thr56 and Ser87) } \rightarrow \text { alter anti-apoptotic } \\
\text { potential of Bcl-2 }\end{array}$ & $\begin{array}{l}\text { De Chiara } \text { et al., } \\
2006\end{array}$ \\
\hline Specific kinases & $\begin{array}{l}\text { Cell } \\
\text { survival }\end{array}$ & $\begin{array}{l}\text { Bcl-2 phosphorylation decreased anti-apoptotic } \\
\text { function }\end{array}$ & $\begin{array}{l}\text { Srivastava } \text { et al., } \\
1999 ; \text { Fan } \text { et al., } \\
\text { 2000; Torcia } \text { et al., } \\
2001 ; \text { De Chiara } \text { et } \\
\text { al., 2006 }\end{array}$ \\
\hline $\begin{array}{l}\text { Nutrient } \\
\text { starvation }\end{array}$ & $\begin{array}{l}\text { Cell } \\
\text { survival }\end{array}$ & $\begin{array}{l}\text { Alanine mutants of Bcl2 (Thr69Ala*, Ser70Ala, } \\
\text { Ser87Ala) lead to binding of Bcl-2-Beclin1 } \\
\text { complex }\end{array}$ & Wei et al., 2008 \\
\hline $\begin{array}{l}\text { IL3-induced } \\
\text { model }\end{array}$ & $\begin{array}{l}\text { Cell } \\
\text { survival }\end{array}$ & $\begin{array}{l}\text { Bcl-2 phosphorylation lead to increased anti- } \\
\text { apoptotic potential }\end{array}$ & $\begin{array}{l}\text { Ito } \text { et al., 1997 } \\
\text { Ginsenoside- } \\
\text { Rh2 induction }\end{array}$ \\
\hline $\begin{array}{l}\text { Taxol-induced } \\
\text { model }\end{array}$ & sell \\
survival & Cell \\
survival & Transient JNK1 activation & $\begin{array}{l}\text { hyperphosphorylation of various kinases } \rightarrow \\
\text { including Raf-1 kinase } \rightarrow \text { Bcl-2 } \\
\text { phosphorylation } \rightarrow \text { strong inhibition of anti- }\end{array}$ & $\begin{array}{l}\text { Blagosklonnyet al., } \\
1996\end{array}$ \\
\hline
\end{tabular}




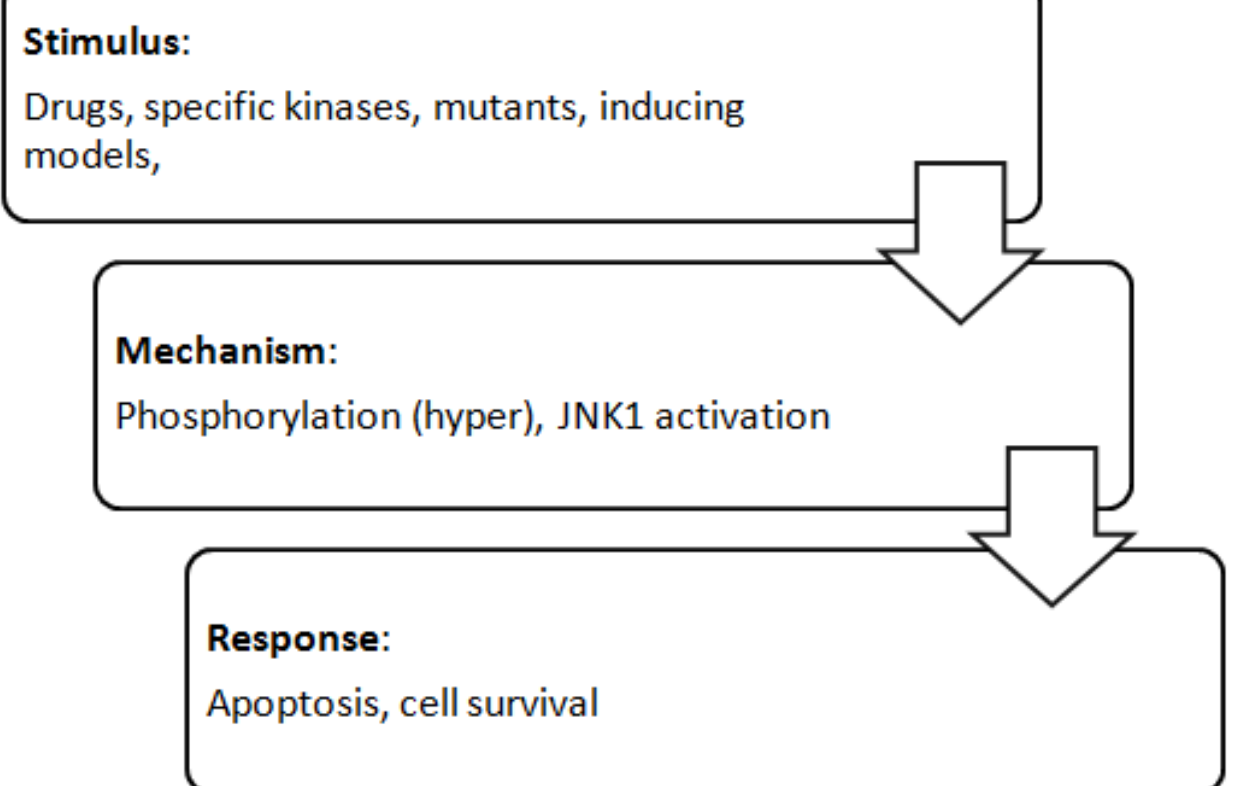

Figure 1 Overview of Phosphorylation, apoptosis and cell survival

\section{Glucocorticoid-induced apoptosis and Bcl-2}

Mitochondria are involved in steroid-induced apoptosis which depends largely upon the phosphorylation of Bcl-2 protein. Cell shrinkage appears to be important feature of apoptosis (Huang and Cidlowski, 2002). It has been observed that Ser70 mutation did not abolish protective effect of Bcl-2 against dexamethasone-induced shrinkage, whereas mutation at Thr56, and 74 and Ser87 abolished the potential of Bcl-2 to inhibit steroid induced cell shrinkage.

Anti-apoptotic behavior of Bcl-2 is inhibited during glucocorticoid-induced apoptosis of T-lymphocytes under the influence of mutation at Thr56 or Ser87 (Huang and Cidlowski, 2002). In lymphoid cells, apoptosis is induced by glucocorticoids whereas, over-expression of Bcl-2 block apoptosis induced by glucocorticoids. Huang and Cidlowski (2002) prepared five transfected Bcl-2 cell lines of WEHI 7.1 cells expressing either alanine mutants of Thr56, Thr74, Ser70 or Ser87. Mutation at Thr56 and Ser87 completely abolished the anti-apoptotic property of Bcl-2 whereas mutation at Ser70 did not alter its ability to block glucocorticoid-induced apoptosis. Interestingly, Thr74 mutation partially disturbed the role of Bcl-2 (Huang and Cidlowski, 2002). 


\section{JNK and IL-3 induced phosphorylation of Bcl-2}

Anti-apoptotic role of Bcl-2 may be enhanced by JNK and/or IL-3 induced phosphorylation at Ser70in murine myeloid cells lacking growth factor (Deng et al., 2001; May et al., 1994).Phosphorylation of Bcl-2 was associated with increased cell survival upon the addition of IL-3 in chemotherapeutic-induced (drug etoposide) apoptosis (Ruvolo et al., 2001). Bryostatin-1 induced vigorous Bcl-2 phosphorylation and promotes cell survival by acting as a strong protein kinase $\mathrm{C}$ (PKC) agonist and found alternate for IL-3 in cell survival. PKC was observed to be specific Bcl-2 kinase responsible for its phosphorylation in the same serine residues both in vivo and in vitro experiments. Seven common phosphorylation sites were found in human and murine Bcl-2 at serine 24, 70, 102, 158, 164, 202 and 213. Moreover, it was investigated that only Ser70 mutation makes the Bcl-2 negative anti-apoptotic in its function reflecting physiological relevance of Bcl-2 phosphorylation at Ser70 (Kennelly and Krebs, 1991; May et al., 1994; Ito et al., 1997).

\section{JNK mediated phosphorylation of Bcl-2}

JNK mediated phosphorylation of Bcl-2 protein is associated not only with programmed cell death but also with autophagy. JNK mediated phosphorylation has been observed to interfere with binding of Bcl-2 to pro-apoptotic $\mathrm{BH} 3$ domain-containing proteins such as Bax and proautophagy BH3 domain-containing proteins such as Beclin-1 (Wei et al., 2008). Kinetic relationship and correlation of Bcl-2 with Bax and Beclin-1, caspase-3 activation as well as Bcl2 phosphorylation was investigated during nutrient starvation (Wei et al., 2008). The nutrient conditions are responsible to regulate the binding of Bcl-2 and Beclin-1 proteins (Pattingre et al., 2005). This binding was minimum during nutrient stress and maximum when the nutrients were in excess. Dissociation of Beclin-1 from Bcl-2 during starvation implicates phosphorylation of Bcl-2 by stress-activated signaling molecule, JNK1 (Wei et al., 2008). During nutrient deprivation, activated JNK induces phosphorylation at multiple sites of Thr69, Ser70 and Ser87 in the non-structured loop of Bcl-2 (located between BH3 and BH4 domains).

Alanine (Thr69Ala, Ser70Ala and Ser87Ala) and non-phosphorylatable Bcl2 mutants, eliminates the starvation-induced separation of Bcl-2 and Beclin-1 and halts autophagy. While, Bcl-2 phosphomimetic mutant (Thr69Glu, Ser70Glu and Ser87Glu) failed to co-immunoprecipitate with Beclin-1 and no autophagy inhibitory activity was observed indicate that JNK mediated multiple site phosphorylation of Bcl-2 activates its separation from Beclin-1 to induce 
autophagy (Wei et al., 2008). Moreover, Bcl-2 phosphorylation suppresses its binding to both BH3-only and multi-domain pro-apoptotic proteins and encourages apoptosis (Bassik et al., 2004). It has been reported that autophagy is activated as a cell survival mechanism during nutrient deprivation (Levine and Klionsky, 2004), while delayed cellular nutrient withdrawal finally leads to apoptosis. In association with the mechanism of autophagy, temporary JNK activation encourages cell survival in contrast to prolonged JNK activation mediates cell death (Ventura et al., 2006; Ham et al., 2003).

\section{Sphingolipid-ceramide and phosphorylation of Bcl-2}

Sphingolipid-ceramide is well known for its apoptogenic behavior by playing crucial role in signal transduction pathways and in cellular stress (Jarvis et al., 1996). Ceramide can activate mitochondrial protein phosphatase (PP2A) which is responsible for apoptosis via dephosphorylation of Bcl-2, phosphorylated Bcl-2 is responsible for cell survival. Ceramide is also responsible for activation of ceramide-activated protein phosphatase (CAPP). However, dynamic phosphorylation/dephosphorylation of Bcl-2 may act as survival sensor during stress stimuli (Dobrowsky et al., 1993; Westwick et al., 1995). Interestingly, Bcl-2 protein has been observed to undergo phosphorylation at various amino acid residues (multiple site phosphorylation) reflecting both apoptotic and anti-apoptotic role (Ruvolo et al., 2001).

\section{Conclusion}

Bcl-2 phosphorylation in response to a range of treatments is specific to stimuli as well as cell type. Phosphorylation sites for $\mathrm{Bcl}-2$ protein identified by investigators are most commonly observed at serine (70 and 87), and threonine (56, 69, 74 and 75). Moreover, transient activation of JNK1 leads to the cell survival while prolonged JNK1 activation leads to cell death reflecting dual role of Bcl-2 protein due to phosphorylation.

\section{Conflict of interest}

The authors declare no conflict of interest.

\section{References}

Ardito F, Giuliani M, Perrone D, Troiano G, Lo Muzio L. The crucial role of protein phosphorylation in cell signaling and its use as targeted therapy. International journal of molecular medicine. 2017; 40(2):271-80.

Bassik MC, Scorrano L, Oakes SA, Pozzan T and Korsmeyer SJ. Phosphorylation of BCL-2 regulates ER Ca2+ homeostasis and apoptosis. EMBO J., 2004;23:1207-16. 
Berg JM, Tymoczko JL andStryer L. Covalent Modification Is a Means of Regulating Enzyme Activity.InBiochemistry. 5th edn., New York: WH Freeman; 2002.

Blagosklonny MV, Chuman Y, Bergan RC, Fojo T. Mitogen-activated protein kinase pathway is dispensable for microtubule-active drug-induced Raf-1/Bcl-2 phosphorylation and apoptosis in leukemia cells. Leukemia. $1999 \mathrm{Jul} ; 13(7): 1028-36$.

Blagosklonny MV, Giannakakou P, el-Deiry WS, Kingston DG, Higgs PI, Neckers L and Fojo T. Raf-1/bcl-2 phosphorylation: a step from microtubule damage to cell death. Cancer Res., 1997; 57: 130-135.

Blagosklonny MV, Schulte T, Nguyen P, Trepel J, Neckers LM. Taxol-induced apoptosis and phosphorylation of Bcl-2 protein involves c-Raf-1 and represents a novel c-Raf-1 signal transduction pathway. Cancer Research. 1996; 56(8):1851-4.

Breitschopf K, Haendeler J, MalchowP, Zeiher AM and Dimmeler S. Post-translational modification of bcl-2 facilitates its proteasome-dependent degradation: molecular characterization of the involved signaling pathway. Mol Cell Biol., 2000; 20: 1886-1896.

Brunelle JK andLetai A. Control of mitochondrial apoptosis by the Bcl-2 family. J Cell Sci., 2009; 122: 437-441.

Chipuk JE and Green DR. How do BCL-2 proteins induce mitochondrial outer membrane permeabilization? Trends Cell Biol., 2008; 18: 157-164.

Choi HJ, Zhu BT. Upregulated cyclin B1/CDK1 mediates apoptosis following 2-methoxyestradiolinduced mitotic catastrophe: Role of Bcl-XL phosphorylation. Steroids. 2019 Oct 1;150:108381.

Colin E, Zala D, Liot G, Rangone H, Borrell-Pagès M, Li XJ, Saudou F and Humbert S. Huntingtin phosphorylation acts as a molecular switch for anterograde/retrograde transport in neurons.EMBO J., 2008; 27(15):2124-34.

De Chiara G, Marcocci ME, Torcia M, Lucibello M, Rosini P, Bonini P, Higashimoto Y, Damonte G, Armirotti A, Amodei S, Palamara AT. Bcl-2 phosphorylation by p38 MAPK Identification of target sites and biologic consequences. Journal of Biological Chemistry. $2006 \mathrm{Jul}$ 28;281(30):21353-61.

Deng X, Xiao L, Lang W, Gao F, Ruvolo P and May WS Jr. Novel role for JNK as a stress-activated Bcl-2 kinase. J Biol Chem., 2001; 276(26):23681-8.

Ding Q, He X, Hsu JM, Xia W, Chen CT, Li LY, Lee DF, Liu JC, Zhong Q and Wang X. Degradation of Mcl-1 by beta-TrCP mediates glycogen synthase kinase 3-induced tumor suppression and chemosensitization. Mol Cell Biol., 2007; 27: 4006-4017. 
Dobrowsky RT, Kamibayasha C, Mumby MC andHannun YA. Ceramide activates a heterotrimeric protein phosphatase 2A. J Biol Chem., 1993; 268: 15523-15530.

Du L, Lyle CS, Obey TB,Gaarde WA, Muir JA, Bennett BL and Chambers TC. Inhibition of cell proliferation and cell cycle progression by specific inhibition of basal JNK activity evidence that mitotic Bcl-2 phosphorylation is JNK-independent.J Biol Chem., 2004; 279(12):1195766.

Ferrell JE Jr and Martin GS. Platelet tyrosine-specific protein phosphorylation is regulated by thrombin.Mol Cell Biol., 1988; 8(9):3603-10.

Franck WL, Gokce E, Randall SM, Oh Y, Eyre A, Muddiman DC and Dean RA. Phosphoproteome Analysis Links Protein Phosphorylation to Cellular Remodeling and Metabolic Adaptation during Magnaportheoryzae Appressorium Development.J Proteome Res., 2015; 14(6):240824.

Fulda S, Gorman AM, Hori O, Samali A. Cellular stress responses: cell survival and cell death.Int J Cell Biol., 2010; 2010: 214074.

Furukawa Y, Iwase S, Kikuchi J, Terui Y, Nakamura M, Yamada H, Kano Y and Matsuda M. Phosphorylation of Bcl-2 protein by CDC2 kinase during G2/M phases and its role in cell cycle regulation.J Biol Chem., 2000;275(28):21661-7.

Greenhalf W, Stephan C and Chaudhuri B. Role of mitochondria and C-terminal membrane anchor of Bcl-2 in Bax induced growth arrest and mortality in Saccharomyces cerevisiae.FEBS Lett., 1996; 380: 169-175.

Gross A, Pilcher K, Blachly-Dyson E, Basso E, Jockel J, Bassik MC, Korsmeyer SJ and Forte M. Biochemical and genetic analysis of the mitochondrial response of yeast to BAX and BCLX(L), Mol Cell Biol.,2000; 20: 3125-3136.

Ham YM, Chun KH, Choi JS, Kim DH and Lee SK. SEK1-dependent JNK1 activation prolongs cell survival during G-Rh2-induced apoptosis. BiochemBiophys Res Commun., 2003;304:35864.

Hill SM, Wrobel L, Rubinsztein DC. Post-translational modifications of Beclin 1 provide multiple strategies for autophagy regulation. Cell Death \& Differentiation. 2019 Apr;26(4):617-29.

Hotchkiss RS, Strasser A, McDunn JE and Swanson PE. Cell death. N Engl J Med., 2009; 361: 15701583.

Huang ST and CidlowskiJA.Phosphorylation status modulates Bcl-2 function during glucocorticoidinduced apoptosis in T lymphocytes. FASEB J., 2002; 16: 825-32. 
Hunter T. Tyrosine phosphorylation: thirty years and counting. CurrOpin Cell Biol., 2009;21(2):140146.

Ito T, Deng X, Carr BK and May WS. Bcl-2 phosphorylation required for anti-apoptosis function. J Biol Chem., 1997; 272: 11671-11673.

Jarvis WD, Grant S andKolesnick RN. Ceramide and the induction of apoptosis. Clin Cancer Res., 1996; 2: 1-6.

Kennelly PJ and Krebs EG. Consensus sequences as substrate specificity determinants for protein kinases and protein phosphatases. J Biol Chem., 1991; 266: 15555-15558.

Kozopas KM, Yang T, Buchan HL, Zhou P and Craig RW. MCL1, a gene expressed in programed myeloid cell differentiation, has sequence similarity to BCL-2. Proc Natl Acad Sci., 1993; 90: 3516-3520.

Krajewski S, Tanaka S, Takayama S, SchiblerMJ, Fenton W and Reed JC. Investigation of the subcellular distribution of the bcl-2 oncoprotein: residence in the nuclear envelope, endoplasmic reticulum, and outer mitochondrial membranes. Cancer Res., 1993; 53: 47014714.

Kvansakul M and Hinds MG. Structural biology of the Bcl-2 family and its mimicry by viral proteins. Cell DeathDiseas., 2013;4: 909.

Letai A, Bassik MC, Walensky LD, Sorcinelli MD, Weiler S andKorsmeyer SJ. Distinct BH3 domains either sensitize or activate mitochondrial apoptosis, serving as prototype cancer therapeutics. Cancer Cell, 2002; 2:183-192.

Levine B and Klionsky DJ. Development by self-digestion: molecular mechanisms and biological functions of autophagy. Dev Cell, 2004;6:463-77.

Maundrell K, Antonsson B, Magnenat E, Camps M, Muda M, Chabert C, Gillieron C, Boschert U, Vial-Knecht E, Martinou JC and Arkinstall S. Bcl-2 undergoes phosphorylation by c-Jun Nterminal kinase/stress-activated protein kinases in the presence of the constitutively active GTP-binding protein Rac1. J Biol Chem., 1997; 272: 25238-25242.

Maurer U, Charvet C, Wagman AS, Dejardin E and Green DR. Glycogen synthase kinase-3 regulates mitochondrial outer membrane permeabilization and apoptosis by destabilization of MCL-1. Mol Cell, 2006; 21: 749-760.

May WS, Tyler PG, Ito T, Armstrong DK, Qatsha KA and Davidson NE. Interleukin-3 and bryostatin-1 mediate hyperphosphorylation of $\mathrm{Bcl}-2 \mathrm{a}$ in association with suppression of apoptosis. J Biol Chem., 1994; 269: 26865-26870. 
Morel C, Carlson SM, White FM and Davis RJ. Mcl-1 integrates the opposing actions of signaling pathways that mediate survival and apoptosis. Mol Cell Biol., 2009; 29: 3845-3852.

Ojala PM, Yamamoto K, Castanos-Velez E, Biberfeld P, Korsmeyer SJ and Makela TP. The apoptotic v-cyclin-CDK6 complex phosphorylates and inactivates Bcl-2. Nat Cell Biol., 2000; 2: 819-825.

Park JG, Aziz N, Cho JY. MKK7, the essential regulator of JNK signaling involved in cancer cell survival: a newly emerging anticancer therapeutic target. Ther Adv Med Oncol. 2019;11:1758835919875574.

Parrish AB, Freel CD and Kornbluth S. Cellular mechanisms controlling caspase activation and function. Cold Spring HarbPerspect Biol., 2013; 5(6): a008672.

Pattingre S, Tassa A, Qu X, Garuti R, Liang XH, Mizushima N, Packer M, Schneider MD and Levine B. Bcl-2 antiapoptotic proteins inhibit Beclin 1-dependent autophagy. Cell, 2005;122:927-39.

Petros AM, Olejniczak ET and Fesik SW. Structural biology of the Bcl-2 family of proteins. Biochimica et Biophysica Acta, 2004; 1644: 83-94.

Popgeorgiev N, Jabbour L, Gillet G. Subcellular localization and dynamics of the Bcl-2 family of proteins. Frontiers in cell and developmental biology. 2018; 6:13.

Poreba M, Groborz K, Navarro M, Snipas SJ, Drag M, Salvesen GS. Caspase selective reagents for diagnosing apoptotic mechanisms. Cell Death \& Differentiation. 2019 Feb;26(2):229-44.

Puttick J, Baker EN andDelbaere LT. Histidine phosphorylation in biological systems. BiochimBiophys Acta. 2008; 1784(1):100-5.

Rechsteiner M and Rogers SW. PEST sequences and regulation by proteolysis. Trends Biochem Sci., 1996; 21: 267-271.

Ruvolo PP, Deng X and May WS. Phosphorylation of Bcl-2 and regulation of apoptosis. Leukemia, 2001; 15: 515-522.

Ruvolo PP, Deng X, Carr BK and May WS. A functional role for mitochondrial protein kinase C alpha in Bcl-2 phosphorylation and suppression of apoptosis. J Biol Chem., 1998; 273: 25436-25442.

Seternes OM, Kidger AM, Keyse SM. Dual-specificity MAP kinase phosphatases in health and disease. Biochimica et Biophysica Acta (BBA)-Molecular Cell Research. 2019 Jan 1;1866(1):124-43.

Srivastava RK, Mi QS, Hardwick JM and Longo DL. Deletion of the loop region of Bcl-2 completely blocks paclitaxel-induced apoptosis. Proc Natl Acad Sci., 1999; 96: 3775-3780. 
Srivastava RK, Srivastava AR,Korsmeyer SJ, Nesterova M, Cho-Chung YS and Longo DL. Involvement of microtubules in the regulation of $\mathrm{Bcl}-2$ phosphorylation and apoptosis through cyclic AMP-dependent protein kinase. Mol Cell Biol., 1998; 18: 3509-3517.

Tamura Y, Simizu S andOsada H. The phosphorylation status and anti-apoptotic activity of Bcl-2 are regulated by ERK and protein phosphatase 2A on the mitochondria.FEBS Lett., 2004; 569(13):249-55.

Terrano DT, Upreti Mand Chambers TC. Cyclin-dependent kinase 1-mediated Bcl-xL/Bcl-2 phosphorylation acts as a functional link coupling mitotic arrest and apoptosis. Mol Cell Biol., 2010;30(3):640-56.

Tummers B, Green DR. Caspase-8: regulating life and death. Immunological reviews. 2017 May;277(1):76-89.

Ventura JJ, Hubner A, Zhang C, Flavell RA, Shokat KM and Davis RJ. Chemical genetic analysis of the time course of signal transduction by JNK. Mol Cell., 2006;21:701-10.

Wang $S$ and El-Deiry WS. TRAIL and apoptosis induction by TNF-family death receptors.Oncogene, 2003; 22(53):8628-33.

Wang YC, Peterson SE and Loring JF. Protein post-translational modifications and regulation of pluripotency in human stem cells. Cell Res., 2014; 24:143-160.

Wang ZH, Ding MX, Chew-ChengSB, Yun JP and Chew EC. Bcl-2 and Bax proteins are nuclear matrix associated proteins. Anticancer Res., 1999; 19: 5445-5449.

Wei Y,Pattingre S, Sinha S, Bassik M and Levine B. JNK1-mediated phosphorylation of Bcl-2 regulates starvation-induced autophagy. Mol Cell., 2008;30:678-88.

Westwick JK, Bielawaska AE, Dbaibo G, Hannun YA and Brenner DA. Ceramide activates the stress-activated protein kinases. J Biol Chem., 1995; 270: 22689-22692.

Yamamoto K, Ichijo H andKorsmeyer SJ. BCL-2 is phosphorylated and inactivated by an ASK1/Jun N-terminal protein kinase pathway normally activated at G2/M. Mol Cell Biol., 1999;19(12):8469-78.

Zhao Y and Jensen ON. Modification-specific proteomics: strategies for characterization of posttranslational modifications using enrichment techniques. Proteomics, 2009; 9(20):4632-41. 